NEW LITERARIA-

An International Journal of Interdisciplinary Studies in Humanities

Volume 3, No. 1, January-February, 2022, PP. 16-22

ISSN: 2582-7375

DOI: https://dx.doi.org/10.48189/nl.2022.v03i1.002

www.newliteraria.com

\title{
Globalization Becoming Instrumental in Re-thinking the Global City: A Postcolonial Reading
}

\author{
Arnab Das and Dr. Madhumita Roy
}

\begin{abstract}
This paper will focus upon how the multi-faceted forces of global capitalism become operational in producing and contributing to the cultural homogeneity on a global scale. In contemporary times, the patterns of urbanization and the hierarchies embedded in them are largely connected to and resulted from the colonial rule. Global cities are characterized by the socio-economic polarizations in the population. The existing inequities between the urban and non-urban populations become more prominent due to direct foreign investments in global cities. Both the architecture and the urban space are affected by the discursive forces of the global cities along with the built environment which also bears the impacts. The significance of the historical processes of globalization have been downplayed in the economic and presentist analyses of how the contemporary global cities are formed. The growth of research has immensely expanded in the last three decades in the history of colonialism and the postcolonial architecture and urbanism. What is reflected in recent studies of postcolonial criticism is that how the postcolonial urbanism is more attentive to the role and activities of the native as alternative voices and visions. This paper will also critically analyze how the term 'global city' has been appropriated by the discursive forces of globalization to represent and reify, a particular aspect of both the city's activity as well as of the world, the world of economy. Hence, postcolonial criticisms become instrumental in dealing with the issues of representations, globalization, nationalism, historiography and cultural identities.
\end{abstract}

Keywords: Capitalism, Globalization, Colonialism, Nationalism, Postcolonialism.

\section{Introduction}

Since 1970s there have been three major factors that contribute to the globalization of economy. These are the banks, the international corporations and the state (Thrift, 1986). Economy has always been the key component for the immense acceleration in both the processes of globalization as well as of the 'global compression' (Robertson, 1987). The massive increase in the international migration of labour and the revolutionary developments in telecommunication technologies and transports have resulted in the cultural deterritorialization. The more general implications of the postcolonial criticism are very crucial for urban studies. It attempts to decentre the Eurocentric notions of the world not only from the perspectives of culture, society and history but also in terms of history as well as of temporality. According to Dipesh Chakrabarty, postcolonial criticism contests the concept that all histories seem to start and conclude with Europe. The urbanists of the $19^{\text {th }}$ century had assumed that the contemporary general study of urbanism should rightfully start with the references to the so called industrial, modern and capitalist city in the West. Such assumptions have been challenged by the contemporary postcolonial criticisms. The capitalist and industrial cities of Europe and 
America bears no autonomous understanding themselves rather they become understandable through references to the economies of the colonial space, processes of urbanization, market systems and culture. There had been many urban revolutions and many other systemic operative structures of cities in the course of the world history apart from the undeniable global importance of the relationships that existed between the industrial urbanism and capitalism. The assumption of 'modernity' is problematic in the sense that it is a term that refers to history or time instead of giving any importance to space. It also does not refer to culture as a way of life. The perceptions of modernity differ simultaneously with the differences in conditions and places. There are many differences between colonial modernity and metropolitan modernity. Similarly, Christian modernity differs from the Islamic modernity. Ethnicity in terms of racial and cultural diversity had been one of the chief characteristics of the 'modern' Western city. It was also a significant characteristic of Batavia in the latter half of the $18^{\text {th }}$ century (Taylor, 1983) and that was long time before it had also become an important characteristic of London or Paris.

Over the last two decades the Western epistemological hegemony and the linguistic dominance of the English have become predominant worldwide. As a result, some of the most extensively circulating urban studies seem to reflect an apparent uniformity in many cities all over the world as they have been narrated through different inter-connected systems of representations. The urban political economy as a discipline through its concepts and narratives have emanated such effects that reduce the wider diversities exiting in different landscapes, topographies, architectures, cultures, languages, histories, identities, memories, religions and polities. It also reduces differences and struggles to bring uniformity and collective wholeness in a series of selective urban social movements, state interventions and collective consumptions. The conceptual invention of the world or the global city widely stems from the dominant American academy which has launched new paradigms by prioritizing the so-called global economy after focusing upon a few cities in Europe or United States and which is supposed to have its roots in Los Angeles or New York (Knox \& Taylor, 1995). The postcolonial critic J. S. Duncan has pointed out Burgess' theory of the city, named as 'concentric zone' in the Chicago school of urban sociology and the effects of this theory were to ensure that all the other cities should be different from Chicago (Duncan, 1996). Similarly, therefore the paradigmatic effects of the world or global city were to instigate both the scholars and the municipal officials to question about the definition of a 'global city'. The fixations, with specific socially constructed concepts of the economy and capitalism, did not direct any reference to the global, cultural and historical conditions in which such concepts were formed, left many questions unanswered regarding the global cities worldwide and the lives of the people lived there. Earlier postcolonial criticisms used to assume that the economic or capitalist paradigms or the theories of those paradigms could create particular socio-cultural worlds which could have significance for those who used them. In contemporary postcolonial criticism to imagine that the universal application of the assumptions of the dominant paradigms can give many different insights about particular places by denying any reference to the histories, memories, diverse identities, politics and subjectivities which exist in particular cities is an illusion.

\section{Literature Review and Discussion}

What is most conspicuous in urban studies, bearing cross-cultural characteristics, is the absence of any reference to the growing societal power and influence of the religious institutions and movements in many cities all over the world. But this does not simply signify that there are particular cities (Jerusalem, Varanasi, Tehran, Belfast, Rome etc.) in the world where to promote and to defend specific religious traditions and identities over centuries have been the defining forces in framing the space and cultural politics of the cities. Hence, the so-called 
'global cities' are shaped by specific religious worldviews and are overwhelmingly and unquestionably understood as 'Christian'. Apart from the cities being the central sites of economic activities, they also act as the sites and symbols of cultural capital. Mostly in recent times the sacred cities particularly have become the sites of intensive religious and political struggles. As for examples of the urban cities with their high-rise buildings becoming the sites of violent religious and political struggles, we may refer to Ayodhya and Amritsar in India, Makka and Jerusalem, significant religious cities, in the Middle East and the World Trade Centre, bearing prominent evidence of violence, in New York. In Europe through the sacral violation and desecration of the old commemorative monuments and past cemeteries new identities have been formed and inscribed. Those new identities have resulted into the sticking of the sacred texts onto the walls of the working classes just as once the graffiti used to be painted. The 1998 communal violence in Jakarta can be referred to in this context. Many of the Indonesian ethnic shops were abolished in that communal violence but those shops that displayed particular Islamic symbols were exempted. The recognition that the subjects living in a world formed by religious beliefs and political worldviews or through alternative reactions that are secular regarding their operational responses can not be inhibited from any agnostic position. The ideological inflations connected to nationalism as well as neo-imperialism reflecting in the proclamations made by New York or London of being global are not at all unconnected to other cities that are simply national.

The contextual viabilities of the terms namely global and globalization are highly contentious. Metaphorically, the term global can be used to refer to the complete or total whole and in a literal sense it may refer to the encompassing of the entire terrestrial globe. In terms of the $20^{\text {th }}$ century economic globalization the conceptual aspects of global or globalization appear to be entirely appropriate in dealing with the global financial services, marketing, gross productions and global warming etc. But when it comes to the applications of those terms in the realms of humanism, society and culture, they appear to operate dubiously. At times the term global seems to be either too broad or too parochial in making advancements to specific economic and ideological agendas. The significance of the transactional forces has been emphasized by all the global discourses. The disruptions, disturbances and denial of the global identity are not revealed due to the multiple everyday practices of coding and decoding, carried out by the global discourses (Kusno, 2000). The global discourses are not merely positioned in the space or place where from they got originated but also from where they have attained disseminations and resulted in utmost consumptions. The material conditions have not only served as the very foundations of both the concepts - global and globalization but they have also made the means of communications such as satellites, electronic platforms, telematics accessible to the global population and have also transformed them into global market commodities. Whenever they refer to globalization, it is described as a highly biased and very uneven process (McGrew, 1992). On the other hand, they designate the global as such a phenomenon which sometimes appears as a discursive privilege for some population and for some others it is completely irrelevant (O'Byrne, 1997). The term global in its connotative sense is mostly ineffective in any of its total, singular or unitary ways of being operative as a metaphor. It fails to identify any of the particular or collective aspirations or desires for the future in worldwide myriad sites. In this postmodern era over the last two decades the urban political economy being a dominant paradigm has secured a significant mark in urban studies (Harvey, 1989; Watson \& Gibson, 1995). Initially the economic discourse gained its predominance all over the world and the global cities in the latter-half of the twentieth century (Knox \& Taylor, 1995). The disintegration of regimes of the eastern Europe had offered new spaces to be analyzed critically at that time. The new concerns regarding the identities, cultural differences and also the representation which had emerged in relation to the global cities could not be addressed properly by the theoretical paradigms of the structuralist analytical approaches. The twentieth century global economic discourse had also failed in addressing 
particular questions bearing urban and architectural symbolisms which were the central concerns of that discourse. The cultural studies had dealt with representations in much of the theoretical literature. These representations sometimes included how meanings were produced through different languages, images and discourses and sometimes they exhibited how linguistic discursivity and visual images overlapped each other as systems of representations (Hall, 1997). But cultural studies failed to define either the symbolic or the built spaces of the global cities.

For over a decade the intensely growing field of postcolonial theory and criticism had literary studies as for its central matter of concern (Moore-Gilbert, 1997). As a narrative recollection of the colonial past and a fruitful gesture towards a pleasant future are reflected in the essays of Postcolonial Spaces (Nalbantoglu and Wong, 1997). In this work the Marxism seemed to have been downgraded to obscurity despite its sustaining the paradigm of the urban political economy for over two decades. Capitalism had never been assumed as an issue of conflict or debate. The colonial spaces started to draw meanings through the process of cultural translation and through the agency of native people as was addressed and contextualized in the work of Yeoh (Duncan,1996). Sir Thomas More described in his "Utopia" (1982) how the originator of an imaginary society had to sacrifice his life to build such a society which was to have a passionate religious belief or ideology as for its very foundations. It was such a society where people could equally participate in and practise Christian communism and all the activities which included education, housing, government, religion, food, clothing war etc. All the Utopians used to share a common belief that the world was ruled by a good and just God. In contemporary times the term 'utopian' is used to refer to an ideal state of social or political perfection which stands against any impractical notions of improvements related to society or politics (More, 1982). The implicit contradictions do neither concern the conditions nor the material aspects of capitalism, environmental issues, colonialism and imperialism. Their functioning should focus upon not how to abolish existing settlements for the sake of establishing new ones rather how the existing situations can be improved. To deal with this new global world what is needed is to have a historical understanding of concepts that are contingent upon history and through which this global world can be put into a new order. Knowledge and imagination both are required to think of a utopian world. Apart from that, which is also very significant is to have a better understanding of the history of the colonial cities and also of the so-called 'Third World'. The future had been pre-figured with much more accuracy in places like Kolkata or Singapore in terms of culture and society of the early twentieth century and the space also played a vital in that. But such a futuristic vision couldn't have been possible in case of London or New York (King, 1991). After the abolition of the twentieth century social experiments what we can now witness is a 're-feudalisation' of the European and American society. This can be seen as an increased relegation into suburban fortresses (Ellin, 1997). In the latter-half of the twentieth century what has become very prominent is that the First and Third World cities have become very similar in distinctive ways. But there have been ever-widening gaps between the two classes of the society - the rich, having the potentiality to secure astronomically high financial assistance, and the poor, permanent members of an impoverished and unemployed class. There have been differences galore in varying degrees between them in the simultaneous existence and production of exuberant office towers and big apartments and the lower-class poverty and vagrancy; classes with residential privileges and classes with the curses of social marginalization and criminal activities. The simultaneous existence of unity, diversity and segregation in terms of ethnicity, race and culture both in the First and the Third World cities have burgeoned to take on the historical characteristics of the colonial cities (King, 1976). The following are the ways in which the issue of the globalized market has been left unchecked and this has resulted in the simultaneous aggravation as well as reduction of the socio-economic divisions through differences in spatial categories. Estimating the last three decades of the twentieth century it 
becomes evident that the differences between the cities and the rural areas in the Third World countries have been diminished and the events have historically been the same in the Western countries as well. Simultaneously, there have been an exacerbation in the scale of differences between the rich and the poor in both the First and the Third World cities. The same logic is applicable to understand the global market networks and the processes through which the global capitalism both reduces as well as degenerates the socio-economic and spatial differences in various cities all over the world. Therefore, the socio-economic and technological standards of the global cities have become increasingly alike even though they continue to possess cultural differences. The spatial differences such as urban and architectural designs and physical forms in the global cities have been lowered down and the globalized population assumes them as being the same. This near uniformity between the them (the global cities) can be interpreted as being the result of the transnational transports of ideologies of the architectural designs, construction materials, transfers of technologies and consumer products. The interests of capitalism have been partially operational through the differences in drawing spatial similarities between the global cities worldwide (Hall, 1991). But the tendencies that have led globalization to exacerbate the differences between the global cities have been the inherent cultural differences and the identity concerns (Robertson, 1992; Nederveen Pietersee, 1996). There have been certain tendencies in the globalized professions of architectural designs and urban or city planning that inextricably seek to give any particular city a visually and spatially distinctive image to the degree to which the global cities appear alike in the gaze of an external observer though for a transnational traveller the real difference becomes prominent in the absence of the local consciousness in the contemporary postcolonial existence of the global cities.

In the last few decades of the twentieth century there had been certain developments that had resulted in a shift to the forms of not only of the city states but also of the city identities. At first, the notions of predetermined national identities, which were introduced in 1989 with the collapse of the Soviet empire, had been destabilized and they also included the subsequent turbulences which were associated with re-forming the national identities in the ever-expanding globalized world. In the twenty first century there had been massive increase in the developments of mobility and migration. Some of those developments had been permanent and some were temporary though both categories had resulted in a massive diaspora. This worldwide diasporic mobilizations of different peoples with their personal and collective connections had been diffused with business and property related interests across different states. Such transmigrations had generated some identity effects that could never be described as singular (Glick Schiller, et al., 1995). These diasporic mobilized people possessed multiple identities and they deployed them wherever they found them suitable to their advantage. The influences and impacts of internet, electronic media, cell phones etc. have empowered people theoretically to make individual and collective decisions freely. The constant needs for updating and changing electronic equipment, software; introduction of new technologies and products and the demographic impacts resulting from such technological changes had necessitated people to retain close contacts with the global cities. The demographic changes that occurred around 1996 had turned half of the world's population to become urban though such historical events passed unnoticed or largely unrecognized (Clark, 1998). Hence, it was not surprising at all that many socio-cultural theorists and visionaries had observed the nation states as the obsolete forms of political, cultural, socio-economic and spatial organizations. Due to economic globalization the significance of the nation states started to shrink. At the same time different big alliances or geopolitical coalitions were formed between the global cities such as North American Free Trade Agreement (NAFTA), Southeast Asia Treaty Organization (SEATO) etc. and many other blocs were also formed between various groups of cities with specialized production services and homogenous ideological and political doctrines. The populations with cultural diversity had been located by both colonialism as well as 
transnational capitalism in the global cities worldwide and that had also encouraged differences and diversities in the functioning of the global cities.

\section{Conclusion}

The use of the term 'global city' can be traced back to the 1980s to refer to the centres of command of the global economy and the global urban operative system. At the very beginning the term had been applied for the main global economic centres - London, Tokyo and New York - that were atop the global urban hierarchy. But gradually the term started to be used interchangeably with terms such as 'world cities. They serve as the key nodes for different functional categories in the transnational urban network. They function as the centres of financial activities, global corporation headquarters, significant transportation nodes, international business institutions and industrial manufacturing centres. Many of the presentday global cities all over the world can be said to have historical territorial reach and infrastructure related communications that can be associated easily with the imperial cities. Globalization as a historical phenomenon described in the accounts given by Robertson, King or Hopkins has been attributed less importance in the evaluations made by the presentist as well as the economic thinkers on the formation of the present-day global cities. Hopkins categorized the different phases of globalization by suggesting that different historical ears contributed to the discursive process of globalization. He refers to globalization's taking its form since the archaic era through the early modern age, the imperial era of the eighteenth century and also through the form of postcolonial globalization of the twentieth century. In laying the socio-economic, cultural and political foundations of the global cities all over the world imperialism has played a significant role both formally and informally. This imperial contribution to the formation of the global cities has been underestimated in literature as is done to the phenomenon called postcolonial migration when the populations shifted from the colonies to some other postcolonial states or to the metropoles. The postcolonial intellectuals from the major global cities such as UK, Australia, Canada and the United States have caused the developments of specific postcolonial cultures and different oppositional forms of knowledge and attempted to dislodge the dominance of the Eurocentric knowledge structure. The English language skill in the postcolonial era of the twenty-first century and the development of the information technology with higher levels of education contributed to the transfer of cultural institutions, employment in different customer services, transcriptions related to medical issues across different global cities in different countries such as USA, Britain, India etc. and that have ultimately brought great impacts in building and developing the postcolonial global urban life. The agglomeration of the global population through the networking of the information technology has enriched the economic advantages of the postcolonial global cities. In contemporary times the magnet of the global city has foregrounded the issues such as the need of being global rather than merely being remained as national and also the concerns of the global human rights. Hence the global cities have become the sites where different global cultures get produced through different disciplines such as science, religion, arts and politics and they have also become the central sites of global outcry, protest and terrorism.

\section{Reference}

Clark, D. (1998). Interdependent urbanization in an urban world: a historical overview. The Geographical Journal, 164(1), 85-95.

Duncan, J. S. (1996). Me(trope)olis: Or Hayden White among the urbanists. In A. D. King (Eds.). Re-Presenting the City: Ethnicity, Capital and Culture in the Twenty-First Century Metropolis. Macmillan.

Ellin, N. (1997). Architecture of Fear. New York: Princeton Architectural Press.

Glick Schiller, et al. (1995). From immigrant to transmigrant: theorizing transnational 
migration. Anthropological Quarterly 68 (1), 48-63.

Hall, S. (1991). The Local and the Global: Globalization and Ethnicity. In A. D. King (Eds.). Culture, Globalization and the World-System: Contemporary Conditions for the Representation of Identity. London: Macmillan.

Hall, S. (1997). Representation: Cultural Representation and Signifying Practices. London: Sage.

Harvey, D. (1989). The Conditions of Postmodernity. Cambridge: Blackwell.

King, A.D. (1976). Colonial Urban Development. London and Boston: Routledge and Kegan Paul.

King, A.D. (1991). Spaces of Culture, Spaces of Knowledge. In A. D. King (Eds.). Culture, Globalization and the World-System: Contemporary Conditions for the Representation of Identity, Minneapolis and London. University of Minnesota Press and Macmillan.

Knox, P. \& P. J. Taylor. (1995). World Cities in a World-System. Cambridge: Cambridge University Press.

Kusno, A. (2000). Behind the Postcolonial: Architecture, Urban Space, and Political Cultures in Indonesia. Routledge: London \& New York.

McGrew, A. (1992). A Global Society. In Stuart Hall, David Held and Tony McGrew (Eds.). Modernity and its Futures. Cambridge: Polity Press in association with the Open University.

Moore-Gilbert, B. (1997). Postcolonial Theory. London: Verso.

More, Thomas. (1982). Utopia. Trans. Paul Turner. Baltimore: Penguin Books.

Nalbantoglu, G. B. \& Chong Thai Wong. (1997). Postcolonial Space(s). Princeton: Princeton University Press.

Nederveen Pieterse, J. (1996). Globalization and culture: three paradigms. Economic and Political Weekly, 3(23), 1389-93.

O’Byrne, D. (1997). Working class culture: local community and global conditions. In J. Eade (Eds.). Living the Global City. London \& New York: Routledge.

Robertson, R. (1987). Globalization Theory and Civilization Analysis. Comparative Civilizations Review 17, 20-30.

Robertson, R. (1992). Globalization: Social Theory and Global Culture. New Delhi: Sage. Taylor, J. G. (1983). The Social World of Batavia. Madison: University of Wisconsin Press. Thrift, N. (1986). The geography of international economic disorder. In R. J. Johnson and P. J. Taylor (Eds.). A World in Crisis? Geographical Perspectives. Oxford: Blackwell.

Watson, S. \& K. Gibson. (1995). Postmodern Cities and Spaces. Oxford: Blackwell.

Yeoh, B. (1996). Contesting Space: Power Relations and the Urban Built Environment in Colonial Singapore. Oxford: Oxford University Press.

\section{Bio-note}

Arnab Das, is a Ph.D. Scholar at the Indian Institute of Engineering Science and Technology, Shibpur, Department of Humanities \& Social Sciences.

Email Id: suvarnabdas@gmail.com

Dr. Madhumita Roy is Assistant Professor in the Department of Humanities \& Social Sciences at Indian Institute of Engineering Science and Technology, Shibpur. She has earned her Ph.D. from IIT Kharagpur, writing her thesis on Salman Rushdie. Her research interests include postcolonial thought and literatures, environmental humanities and urban culture studies. She has published several articles in national and international journals.

Email Id: mroy@hss.iiests.ac.in 